\title{
THE SURTAX ON UNDISTRIBUTED PROFITS OF CORPORATIONS*
}

\author{
HOMER HENDRICISS $†$
}

No part of the Revenue Act of $1936^{1}$ has excited more general interest than that imposing the surtax on undistributed profits of corporations." The tax is new, untried and complicated; the provisions imposing it were hastily drawn. One need not here dwell on its importance as a matter of tax technique and social policy. It is enough to say that under it rates are dependent on what the corporation does or fails to do with its income during the taxable year, and that if action along prescribed lines is not or cannot be taken, the resulting tax may be very large.

It is proposed here to view the new tax, lawyer-wise, as an entity; to outline its major features, indicate the terms of its imposition, and to consider in detail both the Treasury Regulations ${ }^{3}$ promulgated with respect to it, and some of the major interpretative and administrative problems that arise in connection with it. Much is uncertain and will so remain until the courts have acted, or until the Congress amends the statute. So far as possible, however, I shall attempt to suggest, by way of a descriptive analysis of the statute as a whole, how some of the more pressing questions of interpretation arising under it may be resolved.

\section{The Calculation of the Surtax}

The "Surtax on Undistributed Profits" (as the tax is denominated in the heading to Section 14 of the Act) is technically imposed, not directly on undistributed profits (as one would assume from the statutory heading), but rather, by a curious process of adjustments to and deductions from the net income, "upon the net income of every corporation" at rates dependent on the ratios between "undistributed net income" and "adjusted net income". As the Regulations have it, "the surtax im-

*For a complementary study of its effects upon corporate policies and the investor, see Graham, The Undistributed Profits Tax and the Inesslor (1936) 46 YALE L. J. 1. (Ed. Note).

$\div$ Member of the District of Columbia Bar.

1. Pub. L. No. 740, 74th Cong., 2d Sess. (June 22, 1936). References to the 1936 Act will hereafter be merely by section designation.

2. Associations and joint-stock companies are by $\$ 1001$ (a) (2) included within the definition of "corporation", and are thus subject to the tax unless otherwise exempt.

3. 70 Treas. Dec. No. 7 (Int. Rev. 4674) (1936), XV Int. Rev. Bull., No. 32, at p. 2 (1936). The set of applicable regulations is as yet incomplete. Unless otherwise indicated the "Regulations" referred to herein, cited as "Art", are those contained in the above citation.

4. $\S 14(b)$. 
posed by Section 14 of the Act is upon the net income of the corporation but in an amount measured by the undistributed net income". 5 The tax is applicable to each taxable year commencing after December $31,1935,{ }^{\circ}$ and is imposed in addition to the normal tax levied by Section 13.

The process for arriving at the amount of the surtax may be thus outlined:

First, compute the "adjusted net income" which is defined" as meaning the "net income" 8 minus the sum of (a) the normal tax imposed by Section 13 ; (b) the credit provided in Section $26(\mathrm{a})^{0}$ for interest on certain obligations of the United States and Government corporations; (c) the amount allowed as a credit under Section $26(\mathrm{~d}),{ }^{10}$ to a holding company affiliate (as defined in Section 2 of the Banking Act of 1933); and (d) the amount allowed as a credit under Section 26(e) ${ }^{11}$ to a national mortgage association created under Title III of the National Housing Act.

Second, compute the "undistributed net income" which is defined" as the adjusted net income minus the sum of the dividends-paid credit provided in Section $27^{13}$ and the credit provided in Section 26(c), relating to contracts restricting dividends. ${ }^{14}$.

Thus, credits are deducted from the "net income" in arriving at the "adjusted" net income, and additional credits for dividends paid are then deducted from the adjusted net income to fix the "undistributed" net income in respect of which the surtax is imposed. Such a process of arriving at the undistributed net income appears necessary from the standpoint of draftsmanship, because of the nature of the provision for a dividend carry-over from year to year in the calculation of the dividends-paid credit. ${ }^{15}$

Third, the amounts of undistributed net income and adjusted net income having been arrived at by the statutory formulac, the tax is then imposed, by the wording of the Act "upon the net income", but in effect and in actuality on the undistributed portion of the net income, according to rates set by Section $14(\mathrm{~b})$.

\footnotetext{
5. Art. 14-1.

6. $\S 1 ;$ Art. 14-1.

7. $\$ 14(\mathrm{a})(1)$.

8. By $\S 21$ net income is defined as "the gross income computed under $\S 22$, less the deductions allowed by $\S 23$."

9. See p. 24, infra.

10. See p. 24, infra.

11. See p. 24, infra.

12. §14(a) (2).

13. See p. 30, infra.

14. See p. 24, infra.

15. $\$ 27$ (b). See p. 33, infra.
} 
If the "adjusted net income" is less than $\$ 50,000$ a further "specific credit" is allowed in the computation of the tax. ${ }^{10}$

Exemptions. Under Section 14(d) banks as defined in Section 104; insurance companies subject to the tax imposed under Sections 201, 204 , or 207; corporations which, by reason of deriving a large portion of their gross income from sources within a possession of the United States, are entitled to the benefits of Section 251; corporations organized under the China Trade Act of 1922; and joint stock land banks organized under the Federal Farm Loan Act, as amended, are exempt from the surtax on undistributed profits. Certain other classes of corporations, enumerated in Section 101, are also exempt from surtax as well as the normal tax on corporations.

Foreign corporations are likewise exempt from the surtax. It has been suggested that resident taxpayers may avoid the new tax by organizing foreign corporations. But in view of the comparatively high (22 per cent) normal rate imposed on foreign corporations engaged in trade or business or having an office or place of business in this country, ${ }^{12}$ as well as penalty provisions imposing an additional tax in the case of personal holding companies ${ }^{18}$ or of corporations which accumulate their profits with intent to avoid the imposition of the surtax on shareholders, ${ }^{13}$ it would seem that forming a foreign corporation is not a practical way to avoid the new tax.

Domestic corporations which are in bankruptcy, or are insolvent and in receivership are likewise exempt. The condition of bankruptcy or insolvency entitling such a corporation to exemption ${ }^{20}$ need only prevail "for any portion of the taxable year". Thus corporations in bankruptcy or in receivership during the last quarter of the taxable year, seem to be entitled to exemption for the entire year. It would seem, although the matter may be open to doubt, that a corporation over which a court is exercising jurisdiction under $77 \mathrm{~B}$ of the Bankruptcy Act"1 is "in bankruptcy under the laws of the United States" and therefore entitled to exemption. Section 77B is a part of the statutes relating to bankruptcy

16. See p. 22, infra.

17. $\$ 231$.

18. $\$ 351$.

19. $\$ 102$.

20. Neither the Act nor the regulations attempt to define the "insolvency" which is prerequisite to this exemption. But under $\S 1$ of the Bankruptcy Act, 30 Srar. 544 (1898), 11 U.S.C. $\$ 1(15)$ (1934), a person is deemed insolvent whenever "the aggregate of his property . . . shall not, at a fair valuation, be sufficient in amount to pay his dcbts." Insolvency as defined by state law is not necessarily the same. In re Crystal Ice \& Fuel Co., 283 Fed. 1007 (D. Ifont. 1922).

21. 48 Stat. 912 , 11 U.S. C. \$207(a) (1934). See, generally, Friendly, Some Comntents on the Corporate Reorganizations Act (1934) 48 HABv. L. REv. 39. A similar question arises as to railroad corporations over which a court is exercising jurisdiction under the Railroad Reorganization Act, 48 SrAT. 912, 11 U.S.C. §205(a) (1934). 
enacted in pursuance of the federal "bankruptcy power".22 Thus, in proceedings under Section $77 \mathrm{~B}$, the jurisdiction and powers of the court, the duties of the debtor and the rights and liabilities of creditors, and of all persons with respect to the debtor and its property, are said to be the same as if a voluntary petition for adjudication had been entered on the day when the debtor's petition or answer was approved. ${ }^{23}$

\section{The Specific Credit}

In addition. a "specific credit" is provided by Section 14(c) :

"(1) Specific Credit.-If adjusted net income is less than $\$ 50,000$, there shall be allowed a specific credit equal to the portion of the undistributed net income which is in excess of 10 per centum of the adjusted net income and not in excess of $\$ 5,000$, such credit to be applied as provided in paragraph (2).

"(2) Application of Specific Credit.-If the corporation is entitled to a specific credit, the tax shall be equal to the sum of the following: (A) A tax computed under subsection (b) upon the amount of, the undistributed net income reduced by the amount of the specific credit, plus (B) 7 per centum of the amount of the specific credit."

Paragraph (1) thus designates the circumstance (adjusted net income less than $\$ 50,000$ ) entitling a corporation to a specific credit, and tells how the credit shall be computed, while paragraph (2) tells how the credit shall be applied.

What is meant, however, by "the portion of the undistributed net income which is in excess of 10 per centum of the adjusted net income and not in excess of $\$ 5,000 "$ ? Assume that a corporation has an adjusted net income of $\$ \sim 5,000$. It pays no dividends during its taxable year, and is entitled to no credits, other than the specific credit, so that it has for the taxable year an undistributed net income of $\$ 25,000$. Is it permitted a specific credit of $\$ 5,000$ on the theory that the "portion" of the undistributed net income in excess of 10 per centum of the adjusted net inrome is $\$ 22.500$, and that of such portion. $\$ 5.000$ is

22. Cf. Continental Ill. Nat'l Bank \& Tr. Co. of Chicago v. Chicago, R. I. \& P. Ry. 294 U.S. 648 (1935). In the cited case, however, the court held that inability to meet debts as they mature, the condition for the exercise of jurisdiction in these cases, is "something less than a condition of "bankruptcy' or 'insolvency" as those words are employed in the Bankruptcy Act. Id. at 672. The Supreme Court has subsequently indicated that $\S 77 \mathrm{~B}$ is an "integral part" of the Bankruptcy Act. Callaghan v. Reconstruction Finance Corpn., 297 U. S. 464 (1936).

23. 48 STAT. 912,11 U.S.C. $\$ 207$ (o) (1934). Most of the provisions of the Bankruptcy Act are made applicable to proceedings under §77B. See 48 Stat. 912, 11 U. S. C. $\S 207(\mathrm{k})$ (1934). See also Meyer v. Kenmore Granville Hotel Co., 297 U.S. 160 (1936). 
allowable as the specific credit, or is the specific credit $\$ 2,500$ on the theory that the relevant "portion" of the undistributed net income is a total of $\$ 5,000$ and that the difference between the latter figure and 10 per cent of the adjusted net income is the amount of the specific credit? The Treasury Regulations adopt the latter view, and thus state that the credit shall be "an amount equal to the excess of $\$ 5,000$ or the total undistributed net income, whicherer is less, oz'er 10 per cent of the adjusted net income". 24

Notwithstanding the fact that this provision is clearly designed to benefit small corporations, and in the case of any real ambiguity should be construed liberally in favor of such taxpayers, it is believed that close analysis of its terms ${ }^{25}$ reveals no ambiguity and points to the correctness of the Treasury's interpretation. Support for this conclusion may be found in the fact that under the Treasury interpretation the amount of the specific credit $^{20}$ tapers off to zero as the undistributed net income reaches $\$ 50,000,27$ whereas under the opposite interpretation a corporation with an adjusted net income of $\$+9,999$ would pay as much as several hundred dollars less in taxes than one with an adjusted net income of $\$ 1$ more. ${ }^{28}$

Once the amount of the specific credit is determined, its application is comparatively simple. The tax is computed at the rates set by Section 14(b) upon the amount of the undistributed net income as reduced by the amount of the specific credit, to which tax is added 7 per cent of the amount of the specific credit. ${ }^{29}$

\section{Credits in Computing Adjusted Net Ixcope}

For the purpose of computing the surtax, certain credits are allowed in Sections 14(c), 26 and 27 of the Act. except the credit provided in Section 26(b) for dividends received, that being allowed for normal

24. Art. 14-4. Italics supplied.

25. Cf. also the similar phraseology in $\S 1 f(b)$, the provision setting forth the rates of surtax, thus-" 7 per centum of the portion of the undistributed net income which is not in excess of 10 per centum of the adjusted net income: 12 per centum of the portion of the undistributed net income which is in excess of 10 per centum and not in excess of 20 per centum," etc.

26. It is clear that this credit can never exceed $\$ 5,000$, and that in those cases in which the undistributed net income does not exceed $\$ 5,000$, the result produced by the application of the statutory method is obtainable by computing the surtax directly as 7 per cent on the whole of the undistributed net income. See Art. 14-4.

27. Thus in "Example (3)" in Art. 14-4, a corporation with an adjusted net inco ne of $\$ 49,900$ (all undistributed) is shown to be entitled to a specific credit of $\$ 10$ $(\$ 5,000$ less 10 per cent of the adjusted net income, $\$ 4,990=\$ 10)$; whereas under the opposite interpretation the credit in such a case would be $\$ 5,000$.

28. See Comment (1936) If TAX Mag. 493.

29. $\S 14(c)(2)$. 
$\operatorname{tax}$ purposes only. ${ }^{30}$ The credits allowed in the computation of the "adjusted net income" are: (1) the normal tax on corporations imposed by Section 13 ; (2) interest received on certain obligations of the United States and on obligations of Government corporations, if such income is included in gross income under Section 22 of the Act, ${ }^{32}$ provided that such government corporation is an instrumentality of the United States and if under the Statute authorizing the issue of such obligations by the corporation such interest is exempt from normal tax when received by individuals; (3) the amount of the earnings or profits which the Board of Governors of the Federal Reserve System certifies to the Commissioner as devoted by a holding company affiliate (as defined in Section 2 of the Banking Act of 1933) ${ }^{32}$ during the taxable year to the acquisition of readily marketable assets other than bank stock in compliance with Section 5144 of the Revised Statutes. The aggregate of the credits allowable under this provision for all taxable years cannot, however, exceed the amount required to be devoted under Section 5144 to such purposes; $;^{33}$ (4) the amount of the earnings or profits which the Federal Housing Administrator certifies to the Commissioner as applied by a national mortgage association, created under Title III of the National Housing Act, during the taxable year to the acquisition of such reserves as the Administrator may require under the provisions of Section 303 of that Act. ${ }^{34}$

\section{Credits in Computing Undistributed Net Income}

Contracts Restricting Payment of Dizidends. In the second computation, by which the amount of undistributed net income is determined, there is deductible from the adjusted net income "the credit provided in Section 26(c), relating to contracts restricting dividends". ${ }^{35}$

Section 26(c) states:

“(1) Prohibition on Payment of Dividends.-An amount equal to the excess of the adjusted net income over the aggregate of the amounts which can be distributed within the taxable year as dividends without violating a provision of a written contract executed by the corporation prior to May 1, 1936, which provision expressly deals with the payment of dividends. If a corporation would be entitled to a credit under this paragraph because of a contract provision and also to one or more credits because of other contract provisions, only the largest of such credits shall be allowed, and for such purpose

30. See also Art. 26-1.

31. Art. 26-2. See also $\$ \$ 26(a), 25$ (a) (1) and (2).

32. 48 StAT. 162 (1933), 12 U.S.C. $\$ 221$ (a) (1934).

33. $\$ 26(d)$.

34. $\$ 26(\mathrm{e})$.

35. $\$ 14(a)(2)$. 
if two or more credits are equal in amount only one shall be taken into account.

"(2) Disposition of Profits of Taxable Year.-An amount equal to the portion of the earnings and profits of the taxable year which is required ( (by a provision of a written contract executed by the corporation prior to May 1, 1936, which provision expressly deals with the disposition of earnings and profits of the taxable year) to be paid within the taxable year in discharge of a debt, or to be irrevocably set aside within the taxable year for the discharge of a debt; to the extent that such amount has been so paid or set aside. For the purposes of this paragraph, a requirement to pay or set aside an amount equal to a percentage of earnings and profits shall be considered a requirement to pay or set aside such percentage of earnings and profits. As used in this paragraph, the vord 'debt' does not include a debt incurred after April 30, 1936.

"(3) Double Credit Not Allowed.-If both paragraph (1) and paragraph (2) apply, the one of such paragraphs which allows the greater credit shall be applied; and, if the credit allowable under each paragraph is the same, only one of such paragraphs shall be applied."

The Act thus recognizes two general types of contracts in respect of which relief is given: (1) those which prohibit or limit the payment of dividends within the taxable year; and (2) those which require the payment, or irrevocable setting aside, of a portion of the earnings or profits of the taxable year for the discharge of a debt incurred on or before April 30, 1936. Obviously, as stated by the Regulations, the credit is not available under every contract which might operate to restrict the payment of dividends, but only under. those executed by the corporation prior to May 1, 1936, the terms of which satisfy the conditions prescribed in the Act. ${ }^{36}$

It would seem that since the section under consideration was designed to ameliorate a high-rate tax, it should be liberally construed in favor of the taxpayer. The Treasury Regulations, however, give it a strict and narrow construction. This becomes evident from a study of the Regulations pertaining to credits allowed with respect to these restrictive contracts.

Concerning contracts which place a prohibition on payment of dividends, the Regulations state that "the charter of a corporation does not constitute a written contract executed by the corporation within the meaning of Section 26(c) of the Act." Thus, for example, no relief is to be afforded a corporation which is prohibited from paying dividends ky charter provisions, irrespective of whether the prohibition may be found in the charter itself or only when the charter is read in conjunction with

36. Art. 26-3(a). 
state law. ${ }^{37}$ When the charter itself contains no such provision, but it is argued that the state law is a part of the charter and that the payment of dividends is thus prohibited by a "written contract", the Treasury position seems correct. Where, however, the charter contains express provisions prohibiting the payment of dividends, say, on common stock until a certain amount of preferred stock shall have been retired, and the preferred stock has been purchased by outsiders on the faith of such provisions, it would appear that there is here a written contract restricting the payment of dividends within the meaning of the relief provision. It is true that the promoters, and not the corporation, "execute" the charter, but the corporation itself executes the stock certificates. The fact that there is a written contract executed by the corporation should, moreover, be even more clear where the certificates make reference to such restrictive charter provisions. There is no substantial difference between such cases and one where the corporation has executed a separate contract containing the same prohibitions.

The Regulations state that if an amount can be distributed within the taxable year as a dividend in one form (as, for example, in stock or bonds of the corporation) without violating the provisions of the. restrictive contract, but can not be distributed as a dividend in another form (as, for example, in cash) without violating such provisions, the amount is one which, under Section 26(c) (1), can be distributed within the taxable year as a dividend, and is therefore not to be allowed as a credit. The Regulations also conclude that if an amount can be distributed at one time (as, for example, during the last half of the taxable year) without violating the provisions of a contract, but cannot be distributed as a dividend at another time within the taxable year (as, for example, during the first half of the taxable year) without violating such provisions, the amount is one which can be distributed "within the taxable year" without such violation resulting. ${ }^{38}$ In both cases, the Treasury's interpretation, although possibly within the letter of the law, seems nevertheless harsh to the taxpayer.

The requirement that the provisions of the contract "expressly" deal with the payment of dividends is not satisfied if (a) a corporation is merely required periodically to set aside a sum to retire its bonds, or (b) the contract merely provides that while the bonds are outstanding the current assets shall not be reduced below a specified amount. As to the first situation, if the sum for retirement is required to be set aside out of earnings and profits of the taxable year and the other conditions of Section 26(c) (2) are met, relief will be afforded by that provision. In the second case, however, the taxpayer has no prospect

37. As to possible methods of eliminating surplus deficits, see p. 50 , infra.

38. Art. 26-3(b). 
of relief unless the Act be amended; this harsh result arises from the statutory requirement that the contract "expressly" deal with the payment of dividends.

Where a corporation subject to such a contract has an accumulation of earnings and profits at the beginning of the taxable year, built up since February 28, 1913, and dividends can be distributed from such earnings rather than from current earnings without violating the provisions of the contract, the Treasury holds that such earnings must be included in determining "the aggregate of the amounts which can be distributed". The Treasury position is illustrated by the following example:

"For the calendar year 1936 the $A$ Corporation (which was organized in 1918) has a net income (on the accrual basis) of $\$ 200,000$, a normal tax liability of $\$ 28,840$, and an adjusted net income of $\$ 171,160$. At the beginning of the taxable year it had $\$ 50,000$ of accumulated earnings and profits. Its earnings and profits of the taxable year before deducting Federal income taxes amount to $\$ 210,000$. The corporation has second mortgage 6 per cent bonds outstanding at the close of the year, issued prior to Mray 1, 1936, in the amount of $\$ 1,000,000$. An amount of the earnings and profits sufficient to retire 10 per cent of such bonds must, by the provisions of the underlying mortgage, be set aside annually before any dividends can be paid on its stock. The credit allowable under section 26(c) 1 of the Act is $\$ 40,000$, computed as follows:

Adjusted net income $\$ 171,160$

Aggregate of amounts which can be distributed:

Earnings and profits before deducting Federal

income taxes $\ldots \ldots \ldots \ldots \ldots \ldots \ldots \ldots . \$ 210,000$

Less normal tax $\ldots \ldots \ldots \ldots \ldots \ldots \ldots \ldots .28,840$

$\$ 181,160$

Plus earnings and profits at beginning of taxable year accumulated after February 28,1913

50,000

$\$ 231,160$

Less amount required for retirement of bonds 100,000 131,160

Credit allowable $\$ 40,000^{\prime \prime 33}$

Although it is difficult to reach a definite conclusion, it would seem that Section 26(c) (1) probably contemplates that only "amounts" of "adjusted net income", and not any of the income of previous years,

39. Art. 26-3(b) ; see also "Example (2)" therein given. 
shall be taken into account in determining whether or not a distribution of dividends would violate the terms of a contract restricting distribution. If that be true, the Treasury position that the earnings or profits on hand at the beginning of the year need be considered in the circumstances stated, is incorrect, especially in view of the fact that Section 26(c) (1) is a relief provision which should be liberally construed in favor of the taxpayer.

Moreover, it is evidently presupposed by the statute that the "amount which can be distributed" will never be in "excess" of the "adjusted net income". And the amounts which can be distributed may be much in excess of the adjusted net income, if the accumulated earnings of prior years are to be considered. The justifiability of a construction of such a character may be said to be open to question. It appears under the express language of the statute that in order for the provision to become operative, there must be one or more contracts of the specified type restricting the payment of dividends; the adjusted net income is thus invariably in excess of the amounts which can be distributed without violation of the provisions of such a contract resulting.

It is true that Section 26(c) (1), unlike Section. 26(c) (2) which provides for a direct deduction of the amount of adjusted net income which can not be distributed, merely allows a credit for the "excess" of the adjusted net income over the amounts which can be distributed. It would seem, however, that the indirect form of credit allowance was adopted in Section 26(c) (1) not because of any intention to take into account the earnings of prior years, but rather because of the fact that several different contracts of the specified type may have been executed by the corporation and that the purpose was to allow "only the largest of such credits".40

Under Section 26(c) (2), a corporation is also allowed a credit in an amount equal to the portion of the earnings and profits of the taxable year which, by the terms of a written contract executed by the corporation prior to May 1, 1936 and expressly dealing with the disposition of earnings and profits of the taxable year, it is required within the taxable year to pay in, or irrevocably to set aside for, the

40. $\$ 26(c)(1)$. To illustrate: Suppose that a corporation has an adjusted net income of $\$ 100,000$, and has executed two contracts of this type, one of which provides that 10 per cent of such income shall not be distributed and the other that 25 per cent shall not be distributed. It being the purpose of Congress to allow only the larger of such amounts as a credit ( $\$ 25,000$ here), it was much simpler for the draftsmen to write a provision allowing a credit for the excess $(\$ 25,000)$ of the adjusted net income $(\$ 100,000)$ over the amounts which can be distributed $(\$ 75,000)$ than to attempt to draw one allowing direct deductions, especially when it was not known what terms many of the contracts might contain. 
discharge of a debt incurred on or before April 30, 1936. The amount must be actually so paid or set aside. The statute requires further that the contractual provision deal expressly with the disposition of earnings and profits of the taxable year. In pursuance of this requirement, the Regulations hold that a corporation having outstanding bonds is not entitled to a credit under a contractual provision merely requiring it either (a) to retire annually a certain percentage or amount of the bonds, or (b) to maintain a sinking fund sufficient to retire the bonds at maturity, or (c) to pay into a sinking fund for the retirement of the bonds a specified amount per thousand feet of timber cut or per ton of coal mined, or (d) to pay into a sinking fund for the retirement of the bonds an amount equal to a certain percentage of gross sales or gross income. The Treasury apparently believes that such provisions do not expressly deal with the disposition of earnings and profits of the taxable year. But even if examples (a) and (b) are technically correct interpretations of the statute, the interpretation represented by examples (c) and (d) is of doubtful validity; a contract relating to the disposition of gross income, or of amounts which for all practical purposes are portions of gross income, might well be held "expressly" to include the disposition of some part of the earnings and profits which may result from operations during the taxable year. In any event, it must be admitted that the Regulations are clearly right in providing that "a contractual provision . . . shall not be considered as not expressly dealing with the disposition of earnings and profits of the taxable year merely because it deals with such earnings and profits in terms of 'net income,' 'net earnings,' or 'net profits'." 11

The term "debt" as used in Section 26(c) (2) is construed by the Regulations as not including "an obligation of the corporation to a shareholder, as such, as distinguished from a creditor". Thus, amounts paid or set aside in respect of the retirement of preferred stock, pursuant to an agreement underlying the preferred stock issue, are not to be considered as paid or set aside for the discharge of a debt. The position adopted by the Regulations in this respect appears to represent a sound interpretation of the language of the statute.

An indebtedness evidenced by bonds or other similar obligations issued by a corporation is incurred as of the date such obligations are issued, and the amount of such indebtedness is the amount represented by the face value of the obligations. Thus, bond premium or discount has no bearing on the amount of the "debt" for the purposes of the credit. A bond or other similar obligation, moreover, is, according to the Regulations, not issued until it is executed and delivered "to a person who

41. Art. 26-3(c). 
holds it as a debt of the corporation". Even though these interpretations would appear justified, that does not seem true of the Regulation holding that bonds issued after April 30,1936, in exchange in refunding a preexisting issue represent debts incurred after April 30, 1936.

Dividends-Paid Credit. As has been seen, in determining the amount of the "undistributed net income" there is subtracted from the adjusted net income, besides the credit provided in Section 26(c), relating to contracts restricting dividends, the amount of a dividends-paid credit. The latter credit is defined in Section 27 (a) as: " . . . the amount of dividends paid during the taxable year." The term "dividend" is defined in Section 115(a) as meaning:

“ . . . any distribution made by a corporation to its shareholders, whether in money or in other property, (1) out of its earnings or profits accumulated after February 28, 1913, or (2) out of the earnings or profits of the taxable year (computed as of the close of the taxable year without diminution by reason of any distributions made during the taxable year), without regard to the amount of the earnings and profits at the time the distribution was made."

The latter definition requires some explanation. If earnings or profits accumulated after February 28, 1913 are on hand at the time the distribution is made and in an amount sufficient to cover the distribution, they are taxable as a dividend. ${ }^{42}$ If, however, there are no such earnings on hand at the time of distribution, it is nevertheless taxable as a dividend if the earnings or profits of the taxable year (computed as of the close of the taxable year) are in excess of the total amount of the distributions made within such year. ${ }^{43}$ In the event the distributions made during the taxable year exceed the earnings or profits of such year, then, according to the Regulations, "that proportion of each distribution which the total of the earnings or profits of the taxable year bears to the total distributions made during the year shall be regarded as out of the earnings or profits of that year." 44 The Regulations further provide that "the portion of each such distribution which is not regarded as out of earnings or profits of the taxable year shall be considered a taxable dividend to the extent of the earnings or profits accumulated since February 28, 1913, and available on the date of the distribution."

42. On the other hand, if the earnings or profits of the taxable year are in excess of the total amount of distributions made within such year, it is unnecessary to determine whether there are any earnings and profits accumulated since February 28, 1913. See Art. 115-1.

43. Art. 115-1.

44. Art. 115-2. Cf. $\$ 115(\mathrm{~b})$, which provides, in part: "For the purposes of this Act every distribution is made out of earnings or profits to the extent thereof, and from the most recently accumulated earnings or profits." 
One of the major problems of interpretation for the purposes of the statute, when a dividend is paid either in cash or in forms other than cash, is to determine when the dividend is "paid". ${ }^{4}$ The Treasury takes the position that a dividend is "paid" when it is received by the shareholder, and that, consequently, a dividends-paid credit cannot be allowed unless the shareholder receives the dividend during the taxable year for which the credit is claimed. ${ }^{46}$ However, under the Regulations, if a dividend is paid by check, and a check bearing a date within the taxable year is deposited in the mails, in a cover properly stamped and addressed to the shareholder at his last known address at such time that in the ordinary handling of the mails the dividend would be received by the shareholder within the taxable year, a presumption arises that the dividend was paid to the shareholder in such year. ${ }^{47}$ For many corporations this rule may result in a hardship, easily remediable by statutory amendment, arising because it is physically impossible, especially for corporations which maintain large inventories, to estimate accurately the amount of their earnings in time to pay a corresponding amount in dividends during the taxable year. This provision is the result of an amendment in conference, which eliminated a section from the original House bill permitting the credit in cases where the dividends were paid within three months after the close of the taxable year. ${ }^{48}$ However, the presence of the dividend carry-over privilege ${ }^{40}$ does to some degree ameliorate the situation.

The Regulations state that if a corporation, instead of paying the dividend directly to the shareholder, credits the account of the shareholder on the books of the corporation with the amount of the dividend, the credit for a dividend paid will not be allowed unless it be shown to the satisfaction of the Commissioner that such crediting constituted

45. Cf. $\$ 43$ which provides: "The deductions and credits (other than the dividendspaid credit provided in $\$ 27$ ) provided for in this title shall be talien for the tasable year in which 'paid or accrued' or 'paid or incurred,' dependent upon the method of accounting upon the basis of which the net income is computed. . . " The vords vithin the parenthesis mean that the accrual method of arriving at deductions and credits has no application as regards the dividends-paid credit. Thus, Art. 27-1(c) provides: "The determination of whether a taxable dividend has been paid to the shareholder by the corporation during its tasable year is in no way dependent upon the method of accounting regularly employed by the corporation in keeping its books or upon the method of accounting upon the basis of which the net income of the corporation is computed."

46. Art. 27-1(b). Cf. Avery v. Commissioner, 292 U. S. 210 (1934).

47. Art.27-1(b). The payment of a dividend during the taxable year to the authorized agent of the shareholder will be deemed payment of the dividend to the sharehclder during such year.

48. H. R. 12395, 74th Cong., 2d Sess. (1936) §27(a).

49. See p. 33 , infra. 
payment of the dividend to the shareholder within the taxable year..$^{80}$ It should be remembered that if the stockholder includes the amount of the credit as a dividend in his return, the purpose of the dividends-paid credit provision has been complied with. Whether the Commissioner will adopt such an attitude remains to be seen. But if there is to be any doubt whether the facts will show that crediting on the corporate books constituted payment, it would seem safer from the standpoint of the corporation to pay the dividend by the issuance of formal obligations.

In the absence of any new regulations upon the precise issue, ${ }^{\text {bi }}$ earlier regulations may be used to indicate when crediting the shareholder's account constitutes payment to him of the dividend. ${ }^{52}$ In any event, the fact that the corporation may not have sufficient cash on hand with which to pay the amount credited, while relevant in the matter of determining whether the crediting amounts to payment, should not per se preclude the allowance of a dividends-paid credit, especially if the facts are that the corporation is in a position to raise the necessary funds either by loans or by disposal of easily salable properties. ${ }^{53}$

With respect.to credits upon an obligation of the shareholder to the corporation, the Regulations similarly state that the amount of a dividend so credited during the taxable year will not be allowed as a dividends-paid credit to the corporation unless it be shown to the satisfaction of the Commissioner that such crediting constituted payment of the dividend to the shareholder within the taxable year. ${ }^{54}$ If the obligation

50. It would not seem that the Commissioner's decision is final in spite of the wording of the Regulation; clearly, any adverse action by the Commissioner on the matter is reviewable.

51. See, however, Art. 115-1: “. . . A taxable distribution made by a corporation to its shareholders shall be included in the gross income of the distributees when the cash or other property is unqualifiedly made subject to their demands. . . ." See also Hadley v. Commissioner, 36 F. (2d) 543, 544 (App. D. C. 1929).

In Brooks v. Commissioner, 35 F. (2d) 178 (C. C. A. 4th, 1929), the court held that dividends credited to a majority stockholder were income to him, the minority stockholders having withdrawn their dividends and there being no evidence that the petitioner might not have withdrawn the amount credited to him. See, G. C. M. 13193, XIII-1 Cum. Burl. 218 (1934). And see Herbert v. Commissioner, 81 F. (2d) 912 (C. C. A. 3d, 1936), holding that where a dividend was credited to the taxpayer's account he constructively received it and was taxable in respect of it in the year in which it was so credited. Cf. Park v. Gilligan, 293 Fed. 129 (S. D. Ohio 1921), holding that dividends credited to stockholders on the books of the corporation were income only to the extent that they were actually drawn out by the stockholders; if the dividends were available on demand, they were constructively received when credited and the decision is wrong.

52. See U.S. Treas. Reg. 86, Art. 42-2 which, under certain conditions, subjects to tax income though not yet reduced to possession.

53. See Saenger, Inc. v. Commissioner, 84 F. (2d) 23 (C. C. A. 5th, 1936).

54. Art. $27-1$ (b). 
of the shareholder to the corporation is a bona fide obligation, and if the credit is made as a dividend within the taxable year and with the intent that it shall actually reduce the amount of the obligation, there should be no question but that a dividends-paid credit should be allowed to the corporation. ${ }^{65}$

In the case of a stock dividend, ${ }^{50}$ if the shares constituting the dividend are not entered or registered on the books of the corporation in the name of the shareholder (or his nominee or transferee) within the taxable year, the dividend will not be deemed to have been paid in such year. Delivery of a certificate or certificates for such new shares, within the taxable year, constitutes prima facie evidence, under the Regulations, of the payment of the dividend. Similarly, if the dividend is payable in obligations of the corporation, they should be entered or registered in the taxable year on the books of the corporation, in the name of the shareholder (or his nominee or transferee), and, in the case of obligations payable to bearer, should be received in the taxable year by the shareholder (or his nominee or transferee), to constitute payment of the dividend within the taxable year. ${ }^{57}$

Dividend Carry-Over. One of the principal features of the statute is the privilege of carrying forward a credit for dividends paid ${ }^{53}$ in excess of adjusted net income during each of the two years preceding a given taxable year. ${ }^{59}$ Apparently, the purpose of the provision is to permit a certain flexibility in the dividend policy of corporations: high divi-

55. See Cohen v. Commissioner, 77 F. (2d) 184 (C. C. A. 6th, 1935), cert. deried, 296 U. S. 610 (1935); Waggaman v. Helvering, 78 F. (2d) 721 (App. D. C. 1935); Fitch v. Helvering, 70 F. (2d) 583 (C. C. A. Sth, 1934); Hugh H. Xiller, 25 B. T. A. 418 (1932) ; Henry D. Mruller, 16 B. T. A. 1015 (1929); Ids L. Dowling, 13 B. T. A. 787. (1928).

56. As to the classes of stock dividends entitling the corporation to 3 dividends-paid credit, see p. 38 , infra.

57. Art. 27-1(b). In Art. 27-1(d) provision is made for the keeping by the corporntion of records having to do with the dividends-paid credit.

58. The Regulations (Art. 27-2) state that the dividends must be "actually" paid.

59. $\$ 27(b)$. The application of $\$ 27(b)$ is illustrated in Art. 27-2 of the Regulations by certain examples including the following:

"Example (1): The $N$ Corporation has an adjusted net income of $\$ \$ 0,000$ for the calendar year 1936, and during that year pays dividends aggregating $\$ \$ 0,000$. For the calendar year 1937, the corporation has an adjusted net income of $\$ 120,000$ and during that year pays dividends in the amount of $\$ 50,000$. The dividends-paid credit for the calendar year 1937 is $\$ 60,000$, computed as follows:

Dividends paid during 1936 ............................ \$90,000

Adjusted net income for 1936 ...................... 80,000

Excess of dividends paid during 1936 over adjusted net income for that year $\ldots \ldots \ldots \ldots \ldots \ldots \ldots \ldots \ldots \ldots, 10,000$ 
dends are not necessarily penalized, in that the corporation is permitted to get some benefit with respect to future taxes; and a corporation can go through a year or two of low dividends and low taxes, after a particularly good year, by saving a credit for dividend carry-over. ${ }^{00} \mathrm{~A}$ corporation is thus allowed to include in its dividends-paid credit a dividend carry-over from not more than two preceding taxable years, in addition to the credit for dividends paid during the taxable year. The carry-over becomes operative only as to a taxable year in which the dividends paid are less than the adjusted net income; and if there are carry-overs from two taxable years, the earlier one is applied first. ${ }^{01}$ However, by the express provisions of the statute, no credit for this purpose shall be allowed for dividends paid by a corporation "prior to its first taxable year under this title", that is, during any taxable year or period beginning prior to January 1,1936 , since the first taxable year or period in which a corporation may avail itself of the dividend carry-over privilege is its second taxable year or period beginning after December 31, 1935.

A subordinate question of statutory construction arises as to the meaning of the phrase "to the extent not needed as a dividends paid. credit for the taxable year preceding", as used in reference to the amount to be carried over from the second preceding taxable year. The sense of the phrase which seems most consistent with the rest of the statute is that a dividend "not needed as a dividends-paid credit" means not needed as a credit to prevent the imposition of surtax. What effect is to be given in this connection to amounts in respect of which credit is allowed under Section 26(c) relating to contracts restricting dividends? Suppose, for example, that a corporation has an adjusted net income, is entitled to credits under Section 26(c) (2), and also pays dividends, as follows:

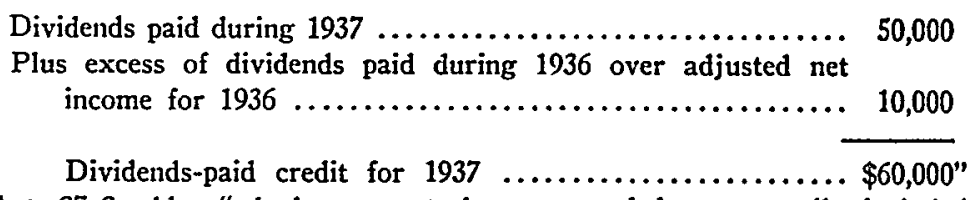

60. Art 27-2 adds: "whether or not the part needed was actually included in the dividends-paid credit of such first preceding taxable year." (My italics). Thus, according to the Regulations, the corporation is allowed no benefit in the later year by reason of any failure, through oversight or otherwise, to claim the entire amount of its dividend credit otherwise allowable for the earlier year. $C f$. The Treasury explanation of "Example (2)" in Art. 27-2.

61. Every corporation claiming a dividend carry-over for any taxable year is required, by the Regulations, to file with its return for such year "a concise statement setting forth the amount of the dividend carry-over claimed and all material and pertinent facts relative thereto, including a detailed schedule showing the computation of the dividend carry-over claimed." See Art. 27-2. 


Adjusted Net
Income
$\$ 100,000$
75,000
100,000

Credit Under
$\$ 26(c)(2)$
$\$ 75,000$
75,000
75,000

Dividends Paid

$\$ 125,000$

None

1938

It must be admitted that a case involving a situation of the kind set forth is not likely to arise. Assuming that it did arise, however, it would seem that, inasmuch as the $\$ 25,000$ excess of dividends paid during 1936 over the adjusted net income of that year is "not needed as a dividends-paid credit" for 1937 (in the sense of a credit to prevent the imposition of the surtax), there should be a carry-over of $\$ 25,000$ as an amount to be allowed in computing the dividends-paid credit for $1938{ }^{62}$

Dividends in Kind. The provisions of the statute which are of the most interest to the corporate taxpayer are those which recognize for the purpose of the credit, dividends other than those paid in cash. ${ }^{13}$ Thus Section 27(c) of the Act provides: "If a dividend is paid in property other than money (including stock of the corporation if held by the corporation as an investment) the dividends paid credit with respect thereto shall be the adjusted basis ${ }^{04}$ of the property in the hands of the corporation at the time of the payment, or the fair market value of the property at the time of the payment, whichever is the lower." 0 s

In the Regulations, ${ }^{\text {, }}$ the Treasury adopts the position that "irrespective of the form of the corporate resolution" by which a dividend is declared, if the dividend is "ultimately and actually paid by the corporation in any property constituting its corporate assets other than money," the taxpayer may claim a dividends-paid credit, the amount of which varies in accordance with the terms of the statute. Thus, in the determination of the dividends-paid credit in respect of dividends paid in lind, it is not material whether (a) the dividend is declared in kind and also paid in kind, or (b) it is declared in cash and paid in assets of the corporation other than cash. $^{67}$

62. See Seidman, Undistributed Profits Tax Problens (1936) 14 Tax Mrac. 453, 497.

63. See Graham, The Undistributed Profits Tax and the Intestor (1936) 46 YaLE L. J., $1,6$.

64. The rules for determining the adjusted basis of property are contained in $\$ 113$.

65. Cf. in this connection $\S 115(j)$ of the 1936 Act which provides that: "If the whole or any part of a dividend is paid to a shareholder in any medium other than money the property received other than money shall be included in gross income at its fair market value at the time as of which it becomes income to the shareliolder."

66. Art. 27-3.

67. It will be interesting to observe whether the Treasury will advocate the same sensible rule in cases involving questions of gain or loss to the corporation on the 
The term "property" as used in Section 27 (c) includes shares of capital stock of the corporation making the dividend distribution if such shares of stock are held by the corporation as an investment. In this connection, the Regulations provide that, unless the contrary is proven, shares of stock once issued but thereafter acquired by the corporation in any manner whatsoever, and not retired, shall be deemed to be held by the corporation as an investment. The Regulations also state that the term "property" as here used includes obligations" upon which the corporation making the distribution is liable as a guarantor, indorser, or surety.

The problem arises whether it is preferable under the provisions of this statute for the corporation to sell the property involved and distribute the proceeds as a cash dividend rather than to pay a dividend in kind. Where the property has appreciated over its adjusted basis to the corporation, there is no tax advantage to be derived from a sale, for the corporation will be subject to normal tax on the gain which is realized; moreover, the resulting gain will serve to increase adjusted net income. Hence, while a larger dividends-paid credit will be obtained as a result of paying a cash dividend of the proceeds, the effect on the amount of undistributed net income which the corporation might otherwise have, will be nil. Where the property has depreciated, however, the sale will result in a capital loss, which may be realized, and used as an offset against any capital gains realized by the corporation during the year. ${ }^{68}$ Since the proceeds, distributed as a cash dividend, will be the same (less expenses of the sale) as the fair market value of the property, the corporation will obtain approximately the same amount of credit for dividends paid as it would have had in the event the property had been distributed as a dividend in kind. ${ }^{69}$

disposition of the property. It would be most illogical to follow one rule for determining the dividends-paid credit and exactly the opposite rule for determining the amount of taxable gain or loss. See Bacon-McMillan Vencer Co., 20 B.T.A. 556 (1930), holding that where a dividend of a definite amount was paid in Liberty bonds of a value in excess of cost, the corporation was taxable on gain from the disposition of the bonds; and Callanan Road Improvement Co., 12 B. T. A. 1109 (1928), holding the corporation realized a deductible loss where a dividend payable in cash was actually paid in Liberty bonds which had depreciated. Cf. General Utilities \& Operating Co. v. Helvering, 296 U. S. 200 (1935); Commissioner v. Columbia Pacific Shipping Co., 77 F. (2d) 759 (C. C. A. 9th, 1935); First Savings Bank of Ogden v. Burnet, 53 F. (2d) 919 (App. D. C., 1931); and Parkersburg Iron \& Steel Co., 17 B. T. A. 74 (1929), aff'd. without discussion of point, 48 F. (2d) 163 (C. C. A. 4th, 1931), holding no gain or loss was realized where dividends were both declared and paid in property.

68. Under $\S 117$ (d), losses from sales or exchanges of capital assets are allowable, in computing net income, to the extent of $\$ 2,000$ plus the gains from such sales or exchanges.

69. Where dividends are paid in kind, it is essential that the corporation determine in advance, as accurately as possible, the adjusted basis of the property and its fair 
Dividends in Obligations of the Corporation. In addition to recognizing dividends in kind for the purpose of the dividends-paid credit, the Act in Section 27(d) provides that dividends in obligations of the corporation shall be credited at their face value, or their market value, whichever is lower; and that when such obligations are redeemed, the difference between their face value and their market price when issued, if it was lower, shall be treated as a dividend paid at the time of redemption $^{70}$ For the purposes of the credit, the form of the corporate resolution by which such dividends are declared is immaterial. ${ }^{71}$ However, the amount allowable in the year of redemption must be diminished by any amounts allowable as a deduction in computing net income of any taxable year, for example, amounts allowable as "deductions for amortized bond discount or bond issue commissions and expenses allocable to the obligations redeemed in computing the net income of the corporation for any taxable year". The Regulations also provide that the corporation is entitled to such additional dividends-paid credit regardless of the identity of the holders of the obligations at the time of their redemption.

Fortunately for the corporate taxpayers, the term "obligations" is defined by the Regulations as "any legal liability on the part of the corporation (not including liability as a guarantor, indorser, or surety), ${ }^{72}$ regardless of when incurred, to pay a fixed or determinable sum of money, evidenced in writing executed by the corporation". ${ }^{23}$ Thus, not only bonds, but notes and debentures are to be classed as obligations; similarly, script if it evidences an obligation to pay a fixed or determinable sum of money, but not a mere option, because that would not evidence an obligation to pay a fixed or determinable sum. Such obligations may be made non-assignable if it be deemed inadvisable that they pass out of "the hands of the stockholders to whom issued. ${ }^{74}$ If they evidence an obligation to pay money, it seems probable that they may within the terms of the statute be made convertible at the option of the holder into stock of the corporation. ${ }^{75}$

market value. Any mistake in the amount of the dividends-paid credit may, on subsequent revision of the figures by the Bureau, result in the imposition of an amount of surtax not contemplated by the taxpayer.

70. The term "redeemed" is defined by Art. 27-4 of the Regulations as including: "(1) repurchase in the open market for investment or sinking fund purposes, (2) retirement, or (3) cancellation of the obligations before, at, or after maturity."

71. Art 27-4. Cf. p. 31, supra.

72. The payment of dividends in obligations of the type specified in the parenthesis is regarded as one in kind and therefore governed by the provisions of $\S 27(\mathrm{c})$. See $p$. 35, supra.

73. Art. 27-4.

74. Non-assignability, however, might affect the market value.

75. Query, however, as to what would be the "face value" of a convertible obligation; $\$ 27$ (d) contemplates that an "obligation" shall have face value. 
Since interest on indebtedness is deductible in computing the net income of the corporation, ${ }^{76}$ there is a certain amount of tax advantage to be derived under the existing law from the payment of dividends in obligations. Amounts paid as interest, which would otherwise be taxable as net income to the corporation from year to year, would, unless distributed as dividends, be subject to the surtax, and even if so distributed, the corporation would be subject to normal tax on them. However, since the principal of the obligations must ultimately be paid, payment of dividends in obligations of the distributor is not advisable unless the corporation believes that it will be in a position to pay the principal out of sums other than those derived from future earnings or profits. ${ }^{77} \mathrm{~A}$ further advantage in dividends in obligations may be in that even after the obligations have been taxed as dividends in the hands of the shareholders, there seems nothing in the statute which would prevent the shareholders, in some future year or years, from surrendering them to the corporation as paid-in surplus or as a contribution to capital. The obligations might also in some future year be exchanged for capital stock of the corporation, as in connection with a recapitalization. ${ }^{78}$

As in the case of dividends in kind, the payment of dividends in obligations will result in administrative difficulties because of the necessity for determining a fair market value for the obligations. If the corporation is wrong in its initial estimate of the fair market value, an unexpected surtax liability may result. There is, of course, some recompense in the fact that whenever the obligations are redeemed, an additional dividends-paid credit (dependent on the fair market value at the time the dividend was paid) may be allowed.

Taxable Stock Dividends. Section 27(e) which allows the sum of taxable stock dividends for the purposes of the dividends-paid credit, will probably become the most important of all the provisions which allow the credit for dividends paid in forms other than cash. The strategy of the section is to allow a dividends-paid credit for stock dividends, at fair market value, ${ }^{\text {,9 }}$ only where the dividends are taxable to the stockholders

76. $\S 23(\mathrm{~b})$.

77. If paid from such earnings or profits, the corporation would not, under existing law, be entitled to a dividends-paid credit as a result of such payment.

78. Cf. $\S 112(\mathrm{~g})(1)(\mathrm{D})$.

79. The "fair market value" is judged as of the time of payment. Where, however, the corporation distributes shares of its own capital stock held as an investment, the amount of the credit is governed by $\S 27(\mathrm{c})$, the provision relating to dividends paid in property, and the credit, therefore, is the adjusted basis of the stock or its fair market value at the time the dividend is paid, whichever is lower. See p. 35, supra. Cf. $\$ 115(\mathrm{~g})$, which provides that if a corporation cancels or redeems its stock (whether or not such stock was issued as a stock dividend) at "such time and in such manner as to make the distribution and cancellation or redemption in whole or in part essentially equivalent to the distribution of a taxable dividend," the amount so distributed, to the extent that it repre- 
as income, under the 16th Amendment. The statute thus straddles the difficult issue of determining when stock dividends are income by putting on the corporation that desires a dividends-paid credit the burden of satisfying the tests of the cases since Eisner v. Macomber. ${ }^{80}$

It is not practicable here to re-examine the metaphysical lines which are supposed to order the distinction between capital and income in the discussion of stock dividends. ${ }^{81}$ There are several views as to what the problems are; one of the simplest and most satisfactory statements of the issue as it now exists is attempted in the Treasury Regulations. There is no conclusive basis for prediction, and the full utility of the stock dividend in connection with the surtax on undistributed profits will wait on decisive litigation.

The Regulations undertake to apply existing rules, intangible as they are, to specific instances likely to recur. Thus:

"The $X$ Corporation had an authorized capital stock of $\$ 300,000$ of common stock, par value $\$ 10$ a share, and $\$ 100,000$ of 7 per cent cumulative preferred stock, par value $\$ 100$ a share, which is preferred as to dividends, has no voting rights, and may be redeemed at any time at $\$ 105$ per share. The articles of incorporation provide that the annual dividend on the preferred stock may be paid in cash or, at the option of the corporation, in one share of common stock for each share of preferred. On July 1, 1936, the $X$ Corporation had outstanding $\$ 200,000$ of common stock and $\$ 100,000$ of preferred stock, earnings and profits of $\$ 60,000$ accumulated since February 28, 1913, and earnings and profits of the tasable year amounting to $\$ 15,000$. On July 1, 1936, it distributed 1,000 shares of its common stock of an aggregate par value (and fair market value) of $\$ 10,000$ to the holders of its preferred stock in payment of the annual dividend on such stock. The stock so distributed constitutes a taxable stock dividend to the holders of the preferred stock."

sents a distribution of earnings or profits accumulated after February 28,1913 , shall be "treated as a taxable dividend". To the extent so treated, the corporation should ba entitled under $\$ 27$ (a) (see p. 30, supra) to a credit for dividends paid, for the tasable year in which the distribution occurs.

80. 252 U. S. 189 (1920).

81. As leading cases, see Koshland v. Helvering, 56 Sup. Ct. 767 (1936); Weiss v. Stearn, 265 U.S. 242 (1924); Rockefeller v. United States, 257 U. S. 176 (1921); Eisner v. Xifacomber, 252 U. S. 189 (1920); United States v. Phellis, 257 U. S. 156 (1921). For general discussions of the problem see Art. 115-3; 2 PAUL ANo Afentens, Law of Federal Incosie Taxation (1934) \$18.26; Rottschaefer, Concept of Income in Federal Tazation (1929) 13 Mins. L. Rev. 637; Maggs, Compulation of Income (1924) 13 Caltr. L. Rev. 13; Seligman, Effects of the Stock Dividend Decision (1921) 21 CoL L REv. 313. 
The above fact situation and holding is substantially identical with that presented the Supreme Court in the recent and important case of Koshland v. Helvering. ${ }^{81 a}$

The Regulations then continue with an example which apparently is based on Eisner v. Macomber:

"On July 1, 1936, the $Y$ Corporation had an authorized capital stock consisting of 1,000 shares of common stock, par value $\$ 100$ a share, of which 500 shares were outstanding. It had earnings and profits of $\$ 40,000$ accumulated since February 28, 1913, and $\$ 5,000$ of earnings and profits of the taxable year. On July 1, 1936, the $Y$ Corporation issued and divided among its shareholders 250 additional shares of its common stock of a total par value of $\$ 25,000$ and transferred an equivalent amount from surplus account to capital stock account. The stock so distributed does not constitute a taxable stock dividend to the shareholders."

The final case set forth states:

"The $Z$ Corporation had an authorized capital stock of 30,000 shares of common, without par value, and 10,000 shares of 7 per cent cumulative preferred stock, par $\$ 100$, which is preferred as to dividends, has voting rights and may be redeemed on the 1st of January or July of any year by the payment of $\$ 105$ per share and accrued dividends. On July 1, 1936, the company's issted and outstanding stock amounted to 20,000 shares of common and 6,000 shares of preferred, and it had $\$ 250,000$ earnings and profits accumulated since February 28, 1913, and $\$ 90,000$ earnings and profits of the taxable year. On July 1, 1936, it paid a dividend on its common stock in preferred stock at the rate of one-tenth share of preferred on each share of common outstanding. The preferred stock so distributed constitutes a taxable stock dividend to the holders of common stock." 82

It is to be noted that in this example of a taxable dividend, the common shareholders received (a) an interest different from that which their former stock holdings represented (preferred shares in respect of common), and (b) that the proportional interests of the original common and preferred shareholders after the distribution were essentially changed.

Thus, the distribution of common stock to preferred shareholders is taxable because the shareholder is receiving something "essentially different" from the equity in the corporation which he already had, within the meaning of the test in the Marr case ${ }^{83}$ similarly, the tax would apply to the distribution to common shareholders of preferred stock having the same rights as preferred already outstanding. It is un-

81a. 56 Sup. Ct. 767 (1936).

82. Art. 115-3.

83. Marr v. United States, 268 U. S. 536 (1925). 
certain as yet, however, whether the tax would apply to a distribution to common shareholders of preferred shares, there being no preferred stock outstanding, or to a distribution of preferred shares, having rights inferior to the outstanding preferred shares. ${ }^{81}$ All that is clear is that the state of the law is so ambiguous that wide experiment with stock dividends can be expected under pressure of the new corporate surtax. It should be remembered that one of the purposes of the tax is to drive financing to the markets, and reduce the volume of self-financing by corporations. One of its results will probably be a translation of corporate surplus accounts into tangible shares of stock, at least for companies which can use their earned surpluses as capital. ${ }^{85}$

Where shareholders have an election or option to receive (a) stock or rights of a class which is exempt, or (b) money or other property ${ }^{83}$ not of an exempt class, and the election to receive money or non-exempt property is exercised by any appreciable number of them, their proportional interests are altered, and, therefore, the transaction is not tax exempt as to any of the shareholders. ${ }^{87}$ The statute provides that such shall be the result whether the election is "exercised" before or after the declaration. The Regulations are broader in that they provide the distribution shall be taxable whether the election is "exercised or exercisable" before or after the declaration. ${ }^{83}$ However, if no shareholder exercises his election to receive money or property not exempt as a dividend, in other words, where all shareholders actually receive stock or rights which, without the election feature in the terms of the distribution, would not be taxable to them as income within the meaning of the Sixteenth Amendment, it may be that the taxability of the transaction

84. Although the proportionate interests of the shareholders in the assets rould not be altered in the situations described in the text, it is arguable that the distributions are taxable for the reason that the common shareholder vould receive "an interest different from that which his former stock holdings represented." Koshland v. Helvering, 56 Sup. Ct. 767 (1936) does not seem to answer the question either way. Cf. Commissioner v. Brown, 69 F. (2d) 602 (C. C. A. 7th, 1934), cert. denicd, 293 U. S. 570 (1934).

85. See Graham, The Undistributed Profits Tax and the Inzestor (1936) 46 Yale L. J., 1,5 .

86. The term "any other property" as used in the statutory provision includes stock: of the corporation or rights to acquire its stock, of a class which if distributed without election would constitute income within the meaning of the Sixteenth Amendment to the Constitution. See Art. 115-4(w).

87. Cf. the language of the majority opinion in Koshland v. Helvering, 56 Sup. $\mathrm{Ct}$. 767 (1936) ; Joseph Paper, 29 B.T.A. 523 (1933); L. Elmer Wood, 29 B.T.A. 735 (1934). But see United States v. Mellon, 281 F. 645 (C. C. A. 3d, 1922); United States v. Davison, 9 F. (2d) 1022 (C.C.A. 3d, 1926), cerl. denied, 271 U.S. 670 (1926); G. C. M. 6709, VIII-2 Cuar. Bull. 132 (1929); and I. T. 2538, IX-1 Cuss. BuLl. 144 (1930), all antedating, of course, Koshland v. Helvering.

88. $\$ 115(\mathrm{f})(2)$; Art. 115-4. 
will be denied; as yet no court has ruled upon such a situation. ${ }^{80}$ In any event, it is clear that in order for Section 115(f) (2) to apply, the right of election by "any" of the shareholders is sufficient and that it is apparently not a condition to the application of the provision that all the shareholders shall have an election. ${ }^{80}$

Distributions in Liquidation. Distributions in liquidation are under Section 27(b) treated as taxable dividends paid, for the purposes of the dividends-paid credit, to the extent that they are chargeable to profits and earnings accumulated since February 28, 1913. Section 27(f) obviously applies whether the liquidation be "complete" or "partial", and it is so construed by the Regulations. It is likewise immaterial that the method of taxation of the distribution is that ordinarily employed with respect to the gain or loss realized and recognized upon an exchange, rather than that employed with respect to a taxable dividend. ${ }^{91}$

According to the Regulations the distribution is to be treated as one constituting in part a distribution of, and properly chargeable to, earnings or profits, if: "(1) under the provisions of Section 115(c) of the Act, the amounts distributed in liquidation are treated as received in payment in exchange for the stock, ${ }^{92}$ and (2) under the provisions of Section 112 of the Act, the gain or loss, if any, from such exchange is recognized." 93

89. Cf. Irving v. United States, 44 F. (2d) 246 (Ct. Cl. 1930), holding that where an 8 per cent dividend was declared, for which the holders of 96 per cent of the stock received stock instead of cash, there was a nontaxable stock dividend as to those receiving stock. Cf. also Jackson v. Commissioner, 51 F. (2d) 650 (C. C. A. 3d, 1931), and George T. Smith, 21 B. T. A. 782 (1930).

90. It is, of course, immaterial to the application of $\S 115(f)(2)$, and the regulations so hold, whether the shareholder is, by the terms of the declaration, obliged to exercise his option affirmatively, or whether payment is to be made in a specified medium unless the shareholder specifically requests payment in the other. See Art. 115-4.

91. Art. 27-6(a).

92. $\$ 115(\mathrm{c})$ provides, in part, that: "Amounts distributed in complete liquidation of a corporation shall be treated as in full payment in exchange for the stock, and amounts distributed in partial liquidation of a corporation shall be treated as in part or fuil payment in exchange for the stock."

93. The Treasury thus construes $\S 27$ (f) as being inapplicable to cases where gain or loss is not recognizable under $\$ 112$. The soundness of the Treasury's position is perhaps indicated by the provisions of $\$ 27(\mathrm{~h})$ which provide that no dividends-paid credit shall be allowable with respect to any part of a distribution which is nontaxable. Note, however, that the Regulation quoted in the text states that "the gain or loss, if any" shall be recognized. It seems unlikely that the Treasury intended to exclude cases arising under $\$ 112(c)(2)$ where in connection with corporate reorganizations a part of the gain is recognized and taxed as a dividend to the shareholders. Cf. Commissioner v. Forhan Realty Co., 75 F. (2d) 268 (C. C. A. 2d, 1935): Commissioner v. Owens, 69 F. (2d) 597 (C. C. A. 5th, 1934) ; George Woodward, 23 B. T. A. 1259 (1931) ; T. W. Henritze, 28 B. T. A. 1173 (1933); and John S. Woodard, 30 B. T. A. 1216 (1934). Clearly, the courts should hold that to the extent any part of the gain in such a case is taxable as a dividend, a dividends-paid credit is allowable to the corporation. 
The Regulations further provide that no dividends-paid credit is allowable with respect to certain transactions described in Sections 112 and 115 of the Act, which for the purposes of the Act are treated, not as distributions to the shareholders of earnings or profits, but as transfers of such earnings or profits intact to another corporation. ${ }^{04}$ Hence in transactions such as the following no dividends-paid credit would be allowed the transferor corporation: (1) A transfer by Corporation $A$ of its properties to Corporation $B$, pursuant to a plan of complete liquidation of Corporation $A$, no gain or loss being recognizable under Section 112 (b) (6) ; (2) The transfer by Corporation $A$ of properties to Corporation $B$, pursuant to a plan of reorganization as defined in Section $112(\mathrm{~g})(1)$, and the distribution in liquidation by Corporation $A$ to its shareholders of stock or securities in Corporation $B$, no gain or loss being recognizable to the shareholders under Section 112 (b) (3). Consequently, although the Regulations permit the transferee and the transferor corporation to make application for an apportionment between them of the dividends-paid credit, it would seem advisable that the transferor corporation pay, in advance and prior to the adoption of the plan of liquidation or reorganization ${ }^{95}$ as the case may be, dividends in the amount

94. Art. 27-6(a). See also note 93, supra. The cited article of the Regulations states that the earnings or profits in the hands of the transferee have "essentiaily the same status" for the purposes of the Act as earnings or profits derived from its own operations. This statement needs some qualification: it may be true that such earnings or profits, if transferred in connection with a nontasable reorganization, are, when distributed by the transferee, taxable to the distributees as a dividend. See $\S 115(\mathrm{~h})$; Commissioner v. Sansome, 60 F. (2d) 931 (C.C.A. 2d, 1932), cert. deried, 287 U.S. 667 (1932); United States v. Kauffmann, 62 F. (2d) 1045 (C. C. A. 9th, 1933); Murchison's Estate v. Commissioner, 76 F. (2d) 641 (C.C.A. 5th, 1935); Fain v. Commissioner, 76 F. (2d) 1008 (C. C.A. 5th, 1935), cert. deried, 296 U. S. $588^{\circ}$ (1935); Harter v. Helvering, 79 F. (2d) 12 (C. C. A. 2d, 1935); Balker v. Commissioner, S0 F. (2d) 813 (C. C.A. 2d, 1936); Helen v. Croctier, 29 B. T. A. 773 (1934). The same rule would probably prevail as to a liquidation which is nontaxable under $\$ 112(b)(6)$. However, it is important to observe that no part of such earnings constitutes income to the transferee, and that the transferee, therefore, is not subject to an undistributed profits surtax with respect to them if it fails to malie a distribution of them within the tasable year. It is, however, entitled to a dividends-paid credit if it distributes such earnings as a dividend. As to possible allocation and apportionment to the transferor, see p. 45 , infra.

95. In the case of reorganizations, if the payment of the dividend is deferred until after the plan has been adopted, there is a very considerable danger that $\$ 112$ (c) vill be held to apply (on the theory that the stockholders received, not a tasable dividend per se, but "other property or money" in addition to stock or securities of the transferee), and in such a case it might be held that the transferor corporation was entitled to a dividends-paid credit only to the extent that the stocltholders were taxable, under $\$ 112(c)(2)$, as having received a dividend. The amounts taxable to the stoclsholders as dividends would, in turn, under $\$ 112$ (c) (1) depend on the respective baces which they had for the stock of the transferor, with the result that it would be impossible 
of its estimated current earnings to the date when it is anticipated the liquidation of the transferor will occur. ${ }^{96}$

In the case of a distribution in liquidation with respect to which a dividends-paid credit is allowable under Section $27(f)$, the amount of the dividends-paid credit is equal to the part of such distribution which is "properly chargeable to the earnings or profits accumulated after February 28, 1913". In other words, for the computation of the credit, there must be deducted from the amount of the distribution that part allocable to capital account. ${ }^{97}$ The "capital account" is stated by the Regulations to include "not only amounts representing the par or stated value of the stock with respect to which the liquidation distribution is being made but also that stock's proper share of the paid-in surplus, and such other corporate items, if any, ${ }^{98}$ which, for purposes of income taxation, are treated like capital in that they are not taxable dividends when distributed but are applied against and reduce the adjusted basis of the stock." The Regulations state that the remainder of the distribution is "ordinarily" properly chargeable to the earnings or profits accumulated since February 28, 1913. While any element of uncertainty is regrettable in regulations interpreting the law, it seems probable that the Treasury. has been as definite in this instance as the circumstances permit. For, it would seem that it is almost impossible to generalize here since the results will depend largely upon the facts of each case, and they must be carefully studied in each instance in order to determine what part of a distribution of this kind is properly chargeable to earnings or profits, and what part to capital.

As has been seen, in certain cases involving a transfer of assets contemplated by Section 112 and in which, therefore, no gain or loss is recognized, the transferor is not in the view of the Treasury entitled to a dividends-paid credit, because the earnings or profits of the transferor on hand at the time of the transfer are regarded as having been trans-

in many cases for the transferor to determine in advance the amount of its dividendspaid credit. It is, of course, arguable that the matter of a dividends-paid credit (since the corporation is, clearly, being liquidated) is governed by $\S 27(f)$ and not $\S 27(h)$. See note 93, supra.

96. There is no possibility of surtax to the transferor corporation as a result of the transfer itself. If there is a $\$ 112$ (b) (6) liquidation, no gain occurs to such corporation because it is merely liquidating its stock; if the transfer be made in connection with a reorganization, and the proceeds of the transfer are distributed in pursuance of the plan of reorganization, no gain is recognizable to the transferor corporation under $\$ 112(d)$.

97. See Art. $27-6(\mathrm{~b})$. The cited article of the Regulations contains an example of the application of the principles stated, illustrating a situation where (1) paid-in surplus and (2) earnings or profits accumulated prior to March 1, 1913, are deemed to be allocable to capital account.

98. Earnings or profits accumulated prior to March 1, 1913, for example. 
ferred intact to another corporation. ${ }^{90}$ Such earnings or profits do not, however, constitute income to the transferee. The transferee is not subject to an undistributed profits surtax with respect to them if it fails to make a distribution of such transferred earnings or profits within the taxable year; however, they become a part of the earnings or profits of the transferee, and when distributed by the transferee are taxable to the distributees as a dividend. And the transferee, in the absence of apportionment under the Regulation about to be considered, is then entitled to a dividends-paid credit in respect of the dividends so paid.

The apportionment privilege was apparently provided to soften the denial to the transferor corporation of any dividends-paid credit for a transfer of its assets in the cases mentioned. It is provided by the Regulations that if the earnings or profits of a corporation shall have become the earnings or profits of another corporation as a result of a transfer during the taxable year of the transferor corporation as described in Section 112 of the Act, any dividends paid by the transferee corporation during that portion of the transferor's taxable year ${ }^{100}$ subsequent to the consummation of such transaction ${ }^{101}$ may, with the approval of the Commissioner, be apportioned and allocated to the transferor corporation and the transferee corporation, respectively, and that the portion so allocated to the transferor corporation may be used only in the computation of the dividends-paid credit allowable to the transferor corporation. ${ }^{102}$

The Regulations state that "upon the audit of the returns, the Commissioner will decide whether the application for apportionment and allocation will be approved." Although it seems probable that any adverse action by the Commissioner is reviewable by the Board of Tax Appeals and the courts, nevertheless corporations will obviously assume some risk if they take it for granted that the application will be allowed. It would appear preferable from the standpoint of the transferor corporation to pay sufficient dividends, in advance of the adoption of any plan for transferring its properties, to ensure that it will have no undistributed net income $;^{103}$ if any excess of earnings develops, by reason of a mistake in the estimates or otherwise, the transferee may, before the end of the taxable year, pay an equivalent amount as dividends, and the two cor-

99. See p. 43 , supra. It is arguable that $\$ 27(f)$, and not $\S 27(h)$ (see p. 47 , infra), applies, and that a dividends-paid credit is therefore allowable to the transferor.

100. It should be noted in passing that the transferor's "tasable year" is a twelve months' period, even though it may be dissolved in the interim. See U. S. Treas. Reg. 86, Art. 47-1.

101. Note that dividends paid by the transferee prior to the time when the transaction is consummated are not subject to apportionment.

102. See Art. 27-6(c).

103. See p. 43 , supra. 
porations can thereupon make application for an apportionment of the same to the transferor. As an alternative the transferor might well insist on protection from the transferee in the form of a contract to pay dividends of a stipulated amount during the period specified, in cases where subsequent to the transaction the persons controlling the transferor will not be able to control the dividend payments of the transferee.

It seems probable that in the usual run of cases the Commissioner will allow the allocation as applied for, especially where the total amount of dividends paid by the two corporations approximates the combined amount of their adjusted net incomes. At the same time, there should be some more definite rule provided, either by amendment of the Regulations, or of the Act if necessary, whereby corporate taxpayers may know in advance that if a transferee pays dividends in a specified amount and within a specified time, they will per se be allocated to the transferor.

Preferential Dividends and Nontaxable Distributions. The final two subsections of the provision concerning the dividends-paid credit are of lesser importance. It is true, however, that part $(\mathrm{g})$, which denies a dividends-paid credit whenever there are irregularities or preferences in the distribution of the dividend, is especially important to close corporations, the owners of which not infrequently divide the profits informally and without strict attention to the numbers or classes of shares owned. The statute by its express terms requires, as a condition for the allowance of a dividends-paid credit, that the distribution shall be (1) "pro rata" and (2) "equal in amount"; and that there shall be (3) "no preference to any share of stock as compared with other shares of the same class". While it does not in terms require that all shareholders of the same class be paid in the same medium, there are obvious dangers in distributing cash to some and property to others, for any mistake in the value of the property might result in a holding that the distribution was not equal in amount. The applicability of the provision is not affected by the "medium in which the distribution is made"; in other words, it applies, not only to cash dividends but to dividends in kind, dividends in obligations, and taxable stock dividends. It applies to "any distribution" as to which a dividends-paid credit might be otherwise allowable, and thus includes a distribution in liquidation referred to in Section 27(f). Furthermore, the disallowance of the credit, where any preference or inequality exists, extends to the entire amount of the distribution and not merely to the part of it which amounts to a preference.

No better illustration of the harshness of the provision, unnecessary because its effect can be avoided comparatively easily, could be given than the following illustration borrowed from the Regulations:

" $A, B, C$, and $D$ are the owners of all the shares of class $A$ common stock in the $M$ Corporation which makes its income returns 
on a calendar year basis. With the consent of all the shareholders, the $M$ Corporation, on July 15,1936, declared a dividend of $\$ 5$ a share payable in cash on August 1,1936 , to $A$. On Septemler 15, 1936 , it declared a dividend of $\$ \mathbf{5}$ a share payable in cash on October 1,1936 , to $B, C$, and $D$. No dividends-paid credit for the taxable year 1936 is allowable to the 11 Corporation with respect to any part of the dividends paid on August 1, 1936, and October 1, 1936." 104

Subsection (h) denies a dividends-paid credit to any distributions which are nontaxable in the hands of the shareholders; it is an omnibus section to cover all cases not specifically provided for. It provides that only such part of the distribution which is not taxable as a dividend shall be denied a dividends-paid credit. The part which is so taxable is allowable as such a credit but must be taxable as a dividend in the hands of "such of the shareholders as are subject to taxation" under Title I of the Act "for the period in which the distribution is made". ${ }^{05}$ But, although certain classes of corporations are exempt from tax ${ }^{108}$ and are not, therefore, "subject to taxation", the fact that dividends paid to them by a corporate taxpayer are not taxable does not prevent the allowance of a dividends-paid credit to the distributor. Nor is such allowance prevented by the fact that the distribution may be made to shareholders who make their returns on a fiscal year basis, during a time when such shareholders are taxable under the provisions of prior acts. ${ }^{107}$ In amplification of this attitude, the applicable Regulation provides that no dividends-paid credit shall be allowed with respect to any part of the distribution which is not properly chargeable to current earnings, or surplus accumulated out of earnings since February 28,$1913 ;^{103}$ or is made by way of stock dividend not taxable to the recipient as income

104. Art. 27-7.

105. $\S 27(\mathrm{~h})$.

106. $\$ 101$.

107. See Art. 27-8. The 1936 Act (see $\$ 1$ ) applies only to taxsable years baginning after December 31, 1935.

108. This is not to be taken as meaning that the distributing corporation invariably shall itself have made or accumulated the earnings or profits. For cxample, certain distributions of earnings or profits accumulated by a transferor corporation are, when distributed by the transferee corporation, taxable to the distributees as dividends. In such cases, the transferee is entitled to a dividends-paid credit; also, under certain conditions, the two corporations may make application for allocation and apportionment to the transferor of dividends paid by the transferee. See p. 45, supra, and Art. 27-6(c).

There is a further provision that "in the case of a corporation which classified as a personal service corporation under the Revenue Act of 1918 or the Revenue Act of 1921, no dividends-paid credit is allowed unless the dividend was paid out of earnings or profits which were taxable in accordance with the provisions of $\$ 218$ of the Revenue Act of 1918 or $\$ 218$ of the Revenue Act of 1921 (see $\S 115(\mathrm{e})$ of the Act)." Sce Art. $27-8(b)$. 
under the Sixteenth Amendment and Articles 115-3 and 115-4 of the Regulations. ${ }^{109}$

Despite the breadth of the federal taxing powers, some doubt has been expressed as to the constitutional validity of this surtax on undistributed corporate profits. While an outline of all the pertinent arguments would be impracticable here, a survey of the statute in action would be incomplete without indicating some points of possible conflict with constitutional doctrines.

A redefinition of "income" may be required if this tax is sustained. For the undistributed profits surtax is not imposed on the receipt of income, but on the disposition which a corporation makes of its income. The question here is whether an income tax must necessarily be imposed only with respect to income receipts and not with respect to income disbursements. A tax on spending, generally imposed on all spending and at rates varying according to the spending which Congress desired to encourage or discourage would, runs the argument, not be sustainable as a tax on "income". It is argued that a tax may not, unless clearly necessary to prevent evasion of the ordinary tax on incomes, be imposed as a result of the use which a taxpayer makes of the income. When the question reaches the courts, more analysis will be required than has as yet been made in any of the decisions regarding the nature of the income tax and the powers which Congress has with respect thereto. The income tax is in its nature an excise. ${ }^{110}$ Heretofore it has been imposed in respect of the receipt of income; whether, if imposed on disbursement or failure to disburse in a specified way, it becomes something other than a tax on income remains to be decided.

The counter argument to the effect that the tax is imposed "upon net income"111 although "measured" by the amount of the undistributed net income ${ }^{112}$ appears to have little force. Even if the denomination by Congress of the tax as a "Surtax on Undistributed Profits"113 be disregarded, the purpose of Congress was, clearly, to force the distribution of profits, and for all practical purposes the tax is imposed on the undistributed portion of the profits. ${ }^{114}$

It is often contended that the tax is necessary in order to force the distribution of profits to stockholders and thus make effective the surtax on individuals, thereby promoting equality of taxation of income from

109. Discussed at p. 38, supra.

110. Brushaber v. Union Pacific R. R. 240 U.S. 1, 16-17 (1916).

111. See $\S 14(b)$.

112. Cf. Art. 14-1.

113. See $\S 14$, headline. See also p. 1, supra.

114. For the disposition of an analogous contention, see Nichols v. Coolidge, 274

U. S. $531,540-541$ (1927). 
business, whether derived from corporations, partnerships, or sole proprietorships. It is to be noted, however, that the surtax in question, unlike that imposed by Section 102 (the accumulation of earnings or profits beyond the reasonable needs of the business and with intent to avoid the imposition of the surtax on shareholders) and the surtax imposed by Section 351 (personal holding companies), is directed against the innocent as well as the guilty. It is the common experience of the business world that the amount of "tax avoidance" which the surtax is professedly designed to prevent is infinitesimal as compared with cases where earnings are retained, not to minimize taxes, but for purposes of expansion, increase of working capital, and for other ends which the business world has regarded as legitimate, although it is now said that financing out of earned surplus results in a misdirection of resources, and should be replaced by financing on the open markets. Whether or not critics are right in viewing the American practice of reinvesting surplus as uneconomic, and whether or not the Federal Government has constitutional power to change the business policy of every corporation in the country by virtue of a new tax, are issues immaterial to the question of how far Congress may go in its anxiety to prevent tax avoidance. The cases in which the Supreme Court has given weight to the preventionof-tax-avoidance argument have involved notorious devices directly affecting the flow of the revenue. ${ }^{115}$

And it must be conceded that there are serious deficiencies in the Act as it now stands from the point of view of that arbitrariness of incidence which may be considered violative of due process. ${ }^{110}$ The argument of due process would have considerable force, especially if raised in cases involving situations where imposition of the tax is made on a corporation which has no income in the business sense during the year, or where the tax results in very great hardship, even penalizing the corporation for not doing what may be impossible; for example, cases in which the corporation has a non-deductible capital loss in excess of its taxable "net income", or where a corporation is unable to meet its debts at maturity

115. Thus, amendments to the estate tax provisions taxing certain linds of tax avoidance transfers have been sustained, Milliken v. United Stztes, 283 U. S. 15 (1931); and provisions having to do with trusts and other transactions directly affecting the productiveness and the equality of the burden of the income tax, Taft v. Bowers, 278 U. S. 470 (1929) ; Corliss v. Bowers, 281 U. S. 376 (1930); Reinecke v. Smith, 289 U. S. 172 (1933) ; Burnet v. Wells, 289 U. S. 670 (1933) ; DuPont v. Commissioner, 259 U.S. 685 (1933).

116. "That a federal statute passed under the taxing power may be so arbitrary and capricious as to cause it to fall before the due process of law clause of the 5 th Amendment is settled." Mr. Justice Sutherland in Heiner v. Donnan, 285 U. S. 312, 326 (1932), citing Nichols v. Coolidge, 274 U. S. 531 (1927), Brushaber v. Union Pacific R. R., 240 U.S. 1 (1916), Tyler v. United States, 281 U.S. 497, 504 (1930). 
if a portion of its earnings and profits be not accumulated for that purpose. Further, the Act contains no provision exempting from the surtax on undistributed profits a corporation which has a surplus deficit and which, therefore, is prohibited by state law from the payment of dividends. But in this case, hardship to the corporate taxpayer can sometimes be avoided by a recapitalization, ${ }^{11 \tau}$ or by a revaluation of assets or by the reduction or elimination of various kinds of reserves, with corresponding adjustments to the surplus account. If the financial condition of the corporation is serious enough. it might even be put into receivership or bankruptcy. ${ }^{118}$

Other illustrations of the force of this accusation of arbitrariness have been given as the article progressed. In some cases, it is true, where the Act may on casual study seem to operate inequitably, a means may often be found within its terms of avoiding serious hardship.

Thus, where a corporation has not sufficient cash with which to pay dividends, the corporate taxpayer may pay dividends in obligations ${ }^{110}$ or in kind ${ }^{120}$ in order to get a dividends-paid credit. The declaration of an optional stock dividend ${ }^{121}$ or the payment of a taxable stock dividend ${ }^{122}$ is also sufficient. The procedure whereby a cash dividend is paid, and followed by a subscription by the shareholders to additional stock in the corporation may possibly be advised; it was cited with approval as a means of relief by two important Treasury witnesses in the hearings on the Bill. ${ }^{123}$ The payment of a cash dividend and the immediate repayment of the same by all the shareholders as a loan to the corporation should perhaps be avoided. ${ }^{124}$ Likewise, where the corporation realizes a large gain, for example, on a sale of property, and the proceeds are not in a form which is easily distributable to shareholders, it is possible for the corporation to transfer the desired amount of the proceeds to a newly organized corporation and pay a dividend in shares of the stock of the new corporation.

117. For example, by reducing the par or stated value of the shares, or converting par stock into no par stock (with an appropriate credit in either case to the surplus account), or by having shareholders surrender the necessary number of shares for retirement.

118. See p. 21, supra.

119. See p. 37, supra.

120. See p. 41 , supra.

121. See p. 35, supra.

122. See p. 38 , supra. There may be serious problems of valuation in all these cases, however.

123. See Hcarings before the Committec on Finance on H. R. 12395, 74th Cong., 2d Sess. (1936) 30-31, 36, 918.

124. Where the loan is evidenced by obligations, the net effect of the transaction would be that the dividend was paid in that form. As to cases where the accounts of the stockholders are merely credited, see p. 31, supra. 
The purpose of this paper has been to describe and analyze the new tax on undistributed profits as an operative fact, using hypothetical cases, in advance of litigation, to make unfamiliar provisions concrete, and to try to visualize the full scope of the Act, by way of a quick survey of its structure. The focus of the article has been directed to the functioning of the statute, as foreshadowed in Treasury Regulations, and compared with the recorded habits and preferences of the courts. Assuming that the surtax is to be a permanent part of the taxing system, it is clear enough, if hardship on a large scale is to be avoided, that it badly needs the discipline of judicial construction and legislative amendment which has characterized the history of the old corporate income tax, and indeed of all complicated legislative experiments in new fields. 